\section{Chilling Duration Affects Foliar Budbreak Of Linden Cultivars}

\author{
Barrett C. Wilson, ${ }^{1}$ \\ Jeff L. Sibley, ${ }^{2}$ and \\ James E. Altland ${ }^{3}$
}

Additional indeX words. chilling, cold storage, dormancy, endodormancy, budbreak, heat requirement, provenance, Tilia

Summary. A study evaluating the effects of varying levels of chilling on foliar budbreak of linden (Tilia spp.) culivars was initiated in 1999 in Auburn, Ala. [lat. $32^{\circ} 36^{\prime} \mathrm{N}$, long. $85^{\circ} 29^{\prime} \mathrm{W}$, elevation $709 \mathrm{ft}(216 \mathrm{~m})$, USDA Hardiness Zone 8a]. Littleleaf linden ( $T$. cordata) 'Greenspire' and 'Fairview' required the most chilling to produce measurable budbreak and exhibited the lowest budbreak percentages. Silver linden ( $T$. tomentosa) 'Sterling' and american linden (T. americana) 'Redmond' needed the fewest hours of chilling to produce budbreak and exhibited the highest budbreak percentages. 'Sterling' was the top performer in foliar budbreak percentage and in subsequent growth. Although 'Redmond' attained high budbreak numbers, its overall growth during the following growing season was inferior to that of 'Sterling', 'Greenspire' and 'Fairview'. This information can contribute to the development of regional planting recommendations, which can aid in the selection of lindens suitable for the area in which they will be grown. Calculated $\mathbf{r}^{2}$ values indicated the models used provided a good fit to the data for all cultivars.

$\overline{\text { Mention of a trademark or proprietary product does }}$ not imply endorsement of the products named or criticism of other products not named that may also be suitable.

${ }^{1}$ Graduate research assistant, Department of Horticulture, Auburn University, 101 Funchess Hall, Auburn University, AL 36849

${ }^{2}$ Associate professor, Department of Horticulture, Auburn University, 101 Funchess Hall, Auburn University, AL 36849

${ }^{3}$ Assistant professor, North Willamette Research and Extension Center, Oregon State University, 15210 NE Miley Road, Aurora, OR 97002-9543.
L indens are large, deciduous shade trees $[50$ to $80 \mathrm{ft}$ (15.2 to $24.4 \mathrm{~m})$ tall and 25 to $50 \mathrm{ft}(7.6$ to $15.2 \mathrm{~m})$ wide] found in much of the northern hemisphere, with species native to North America, Europe, and Asia. They produce exceptional shade with dark green leaves and a stately, beautiful form. There are about 10 cultivars of american linden (USDA Zones $3 \mathrm{~b}$ to 8 ), 23 cultivars of littleleaf linden (USDA Zones3b to 7 ), and 5 cultivars of silver linden (USDA Zones 4 to 7) (Dirr, 1998). Of the readily available cultivars, few have gained popularity in the southern U.S., probably a result of the prevailing belief that lindens are northern trees with poor performance in the southern states.

Research suggests that performance of cultivars and selections of woody ornamentals can vary greatly depending upon their provenance or area of origin, as was the case with sugar maple (Acer saccharum) and red maple (Acer rubrum) as well as other species (Kriebel and Wang, 1962; Perry and Hellmers, 1973; Sibley et al., 1995, 1999; Townsend et al., 1982). Trees in previous studies exhibited differences in date of budbreak, budbreak numbers, stem diameter and elongation, root growth, leaf retention, fall color, flowering and fruiting, and winter injury.

One of the determining factors causing variations in growth and performance of woody plants is release of bud endodormancy through chilling responses. The influence of chilling temperatures during the dormant season is widely known for fruit trees, but not ornamental trees. Chilling affects timing and amount of vegetative and floral budbreak of woody plants, as well as subsequent growth, development, and hardiness (Couvillon and Erez, 1985; Dokoozlian, 1999; Mahmood et al., 2000; Murray et al., 1989; Roberts and Zwiazek, 1999). Ashby's (1962) work with american linden showed that increased chilling led to a significantly faster rate of budbreak. The least chilled plants, which broke bud and began growth later, also stopped growth and began losing leaves at a later date. As a result, the growth periods between chilling treatments did not vary greatly. In other research, some lindens lifted from the field in the fall and stored at $38^{\circ} \mathrm{F}$ $\left(3.3^{\circ} \mathrm{C}\right)$ through spring had partial budbreak while still in cold storage. Trees receiving minimal chilling did not break bud at all.

The objectives of this study were to determine if selected linden species and cultivars respond differently to chilling and to estimate the chilling requirement for the selections. From this information and future research, regional planting recommendations can be determined to assist in the selection of lindens suitable for southern landscapes.

\section{Materials and methods}

Tissue cultured plants of littleleaf linden 'Greenspire' (Greenspire ${ }^{\circledR}$ ) and 'Fairview' (Fairview ${ }^{\mathrm{TM}}$ ), silver linden 'Sterling', and american linden 'Redmond' were obtained as 4 to 5 -ft (1.2 to $1.5-\mathrm{m}$ ) tall bare-root, whips in February 1999. The trees were planted into 7 -gal $(22.0$-L) containers in a 6 pinebark : 1 sand (by volume) substrate amended with $5 \mathrm{lb} /$ yard $^{3}(3.0$ $\mathrm{kg} \cdot \mathrm{m}^{-3}$ ) dolomitic limestone, $1.5 \mathrm{lb} /$ $\operatorname{yard}^{3}\left(0.9 \mathrm{~kg} \cdot \mathrm{m}^{-3}\right)$ Micromax (O.M. Scott Co., Marysville, Ohio), and 11.1 $\mathrm{lb} / \operatorname{yard}^{3}\left(6.3 \mathrm{~kg} \cdot \mathrm{m}^{-3}\right)$ of $18-6-12$ (18N-2.6P-10K) Osmocote (O.M. Scott Co.). Trees were grown in full sun under overhead irrigation for 10 months in Auburn, Ala. [lat. $32^{\circ} 36^{\prime} \mathrm{N}$, long. $85^{\circ} 29^{\prime} \mathrm{W}$, USDA Hardiness Zone $8 \mathrm{a}$, elevation $709 \mathrm{ft}(216 \mathrm{~m})]$ until December 1999.

The study consisted of six durations of chilling, applied in increments of $200 \mathrm{~h}$, to each cultivar (200 to 1200 $\mathrm{h}$ ), with each treatment consisting of three single-tree replications per cultivar. Chilling was considered as total $h$ below $45^{\circ} \mathrm{F}\left(7.2^{\circ} \mathrm{C}\right)$ beginning 1 Oct. using the "Old 45 Chilling Model" (Powell et al., 1999). Upon natural accumulation of $200 \mathrm{~h}$ of chilling in December 1999, the first treatment was placed in a glass greenhouse maintained at a minimum temperature of $72^{\circ} \mathrm{F}\left(22.2^{\circ} \mathrm{C}\right)$. Subsequent treatments were placed in the greenhouse at intervals of $200 \mathrm{~h}$ and were weeded and watered by hand as needed. Trees were arranged in a completely randomized design. Auburn normally receives 900 to $1000 \mathrm{~h}$ of natural chilling, therefore plants in treatments 1 to $4(200$ to $800 \mathrm{~h})$ were allowed to accumulate natural chilling. Plants in treatments 5 to $6(1000$ to $1200 \mathrm{~h})$ accumulated $925 \mathrm{~h}$ of natural chilling through March 2000, with the remainder added while stored at $38^{\circ} \mathrm{F}$ 
$\left(3.3{ }^{\circ} \mathrm{C}\right)$ in a thermostatically controlled cooling unit because of warming temperatures outdoors. When the study was terminated in April 2000, heat units [total h at a minimum of 72 $\left.{ }^{\circ} \mathrm{F}\left(22.2^{\circ} \mathrm{C}\right)\right]$ accumulated in the greenhouse ranged from $2856 \mathrm{~h}$ for treatment 1 to $504 \mathrm{~h}$ for treatment 6 .

After placement in the greenhouse, the trees were monitored twice weekly for foliar budbreak. The total number of buds was counted for each tree. Budbreak was considered to be the point where overlapping bud scales began to separate, revealing leaf tips. The highest budbreak count recorded for each cultivar by the end of the study was recorded. Heat units required to reach a given budbreak percentage were estimated from the observed budbreak percentages and accumulated heat units for each treatment and cultivar using regression analysis. The SAS stepwise procedure was used to determine the best model for each cultivar (SAS, Chicago), using the $R^{2}$ and Mallow's C criteria (Neter et al., 1996) in the selection process.

\section{Results and discussion}

Predicted heat units required for initial, 10\%, 25\%, and 50\% budbreak were estimated based on observations. Regression analysis indicated a similar polynomial model (though different coefficients for each cultivar) as the most accurate for predicting heat units in each cultivar: $Y=\beta_{1} x_{1}+\beta_{2} x_{1}{ }^{2}+\beta_{3} x_{2}$ $+\beta_{4} x_{2}^{2}$, where $Y=$ heat units, $x_{1}=$ chilling hours, and $\mathrm{x}_{2}=$ percent budbreak.

For all cultivars, increasing the duration of chilling accelerated the rate of foliar budbreak. Increased chilling reduced the number of heat units required to initiate foliar budbreak (Table 1) and generally led to an increase in budbreak percentage. All

Table 1. Predicted number of heat units required to reach a given budbreak percentage on selected linden (Tilia spp.) cultivars.

\begin{tabular}{|c|c|c|c|c|c|}
\hline \multirow[b]{2}{*}{ Cultivar } & \multirow[b]{2}{*}{$\begin{array}{l}\text { Hours } \\
\text { chilled }\end{array}$} & \multicolumn{4}{|c|}{ Predicted number of heat units ${ }^{\mathrm{z}}$} \\
\hline & & $\begin{array}{c}\text { Initial } \\
\text { budbreak }\end{array}$ & $\begin{array}{c}10 \% \\
\text { budbreak }\end{array}$ & $\begin{array}{c}25 \% \\
\text { budbreak }\end{array}$ & $\begin{array}{c}50 \% \\
\text { budbreak }\end{array}$ \\
\hline \multirow{7}{*}{$\begin{array}{l}\text { Littleleaf linden } \\
\text { 'Greenspire' }\end{array}$} & 200 & $1935^{y}$ & 2370 & 2843 & $--^{x}$ \\
\hline & 400 & 1389 & 1824 & 2297 & 2604 \\
\hline & 600 & 922 & 1357 & 1830 & 2137 \\
\hline & 800 & 535 & 970 & 1442 & 1750 \\
\hline & 1000 & 227 & 662 & 1134 & 1442 \\
\hline & 1200 & --- & 433 & 906 & 1213 \\
\hline & & \multicolumn{4}{|c|}{$r^{2}=0.58$} \\
\hline \multirow{7}{*}{$\begin{array}{l}\text { Littleleaf linden } \\
\text { 'Fairview' }\end{array}$} & 200 & 1925 & 2320 & 2760 & --- \\
\hline & 400 & 1368 & 1763 & 2203 & 2532 \\
\hline & 600 & 883 & 1278 & 1718 & 2047 \\
\hline & 800 & 470 & 865 & 1306 & 1634 \\
\hline & 1000 & 130 & 524 & 965 & 1293 \\
\hline & 1200 & --- & 256 & 696 & 1024 \\
\hline & & \multicolumn{4}{|c|}{$r^{2}=0.65$} \\
\hline Silver linden & 200 & 1952 & 2173 & 2442 & 2729 \\
\hline \multirow[t]{6}{*}{ 'Sterling' } & 400 & 1286 & 1506 & 1776 & 2062 \\
\hline & 600 & 739 & 959 & 1229 & 1515 \\
\hline & 800 & 311 & 531 & 801 & 1087 \\
\hline & 1000 & 2 & 223 & 493 & 779 \\
\hline & 1200 & --- & 34 & 304 & 590 \\
\hline & & \multicolumn{4}{|c|}{$r^{2}=0.66$} \\
\hline American linden & 200 & 1900 & 2293 & 2723 & --- \\
\hline \multirow[t]{6}{*}{ 'Redmond' } & 400 & 1268 & 1661 & 2091 & 2382 \\
\hline & 600 & 747 & 1141 & 1571 & 1861 \\
\hline & 800 & 337 & 730 & 1160 & 1451 \\
\hline & 1000 & 38 & 431 & 861 & 1152 \\
\hline & 1200 & --- & 243 & 672 & 963 \\
\hline & & \multicolumn{4}{|c|}{$r^{2}=0.71$} \\
\hline
\end{tabular}

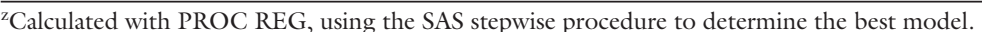

y One heat unit equals $\mathrm{l} \mathrm{h}$ in the greenhouse at a temperature of at least $72{ }^{\circ} \mathrm{F}\left(22.2^{\circ} \mathrm{C}\right)$.

${ }^{x}$ Predicted heat unit level was less than or greater than that which was applied.

walues represent percent variation explained by the model. cultivars required over 1900 heat units to initiate budbreak after $200 \mathrm{~h}$ of chilling, but only 739 to 922 heat units after $600 \mathrm{~h}$ and between 2 to 227 heat units following $1000 \mathrm{~h}$ of chilling for initiation of budbreak. Calculated $r^{2}$ values indicate the model selected provided a good fit to the data for all cultivars.

Heat units required for initial budbreak were similar for 'Sterling' and 'Redmond'. Although the model predicted heat units required for budbreak to occur for 'Greenspire' and 'Fairview', actual budbreak was never observed for these cultivars in trees receiving only $200 \mathrm{~h}$ of chilling. 'Greenspire' and 'Fairview' trees receiving $200 \mathrm{~h}$ of chilling eventually declined to a point of death. Silver linden 'Sterling' performed well in this study and was the only cultivar receiving $200 \mathrm{~h}$ of chilling that reached $50 \%$ budbreak by the time the trees were moved from the greenhouse and transplanted to larger containers (Table 1).

The optimal chilling range for 'Greenspire' began at 800 to $1000 \mathrm{~h}$, with $25 \%$ to $50 \%$ budbreak occurring after accumulation of 1134 to 1750 heat units. 'Fairview' produced minimal budbreak after $400 \mathrm{~h}$, with an optimal range of 800 to $1000 \mathrm{~h}$ and $25 \%$ to $50 \%$ budbreak with 965 to 1634 heat units. An optimal chilling range for 'Sterling' was 600 to $800 \mathrm{~h}$ with $25 \%$ to $50 \%$ budbreak occurring after accumulation of 801 to 1515 heat units. 'Redmond', an american linden, exhibited sparse budbreak after only $200 \mathrm{~h}$ of chilling, with a wide optimal chilling range of 600 to 1000 h producing $25 \%$ to $50 \%$ budbreak after accumulation of 861 to 1861 heat units.

Further study is needed to determine absolute chilling requirements for the various linden cultivars. Other topics that merit further study include the contrasting effects of cold storage chilling and natural outdoor chilling, and determination of optimal chilling temperatures. Also, greenhouse temperatures during budbreak and growth tend to remain constant while outdoor temperatures fluctuate. The work presented here indicates that littleleaf lindens 'Greenspire' and 'Fairview' have the highest chilling requirement of the selections evaluated. Silver linden 'Sterling' exhibited the highest budbreak percentage of all selections across all treatments evaluated. American lin- 
den 'Redmond' and silver linden 'Sterling' required the fewest hours of chilling to produce measurable foliar budbreak.

Following termination of the greenhouse portion of this study, all trees were moved back to the growing area outdoors to allow observation of subsequent growth. By the end of the growing season in Fall 2000, differences observed in initial budbreak were magnified. Trees within each cultivar that had received greater amounts of chilling were larger than trees receiving less chilling. Furthermore, the overall growth was greater on 'Sterling' than the other cultivars, with the least overall growth occurring for 'Redmond'.

This study provides an indication of the need to carefully select lindens suitable for the region in which they will be grown, whether in field or container production or in the landscape. Based on the results of this study, considering the parameters evaluated for these four linden cultivars, 'Sterling' appears to be the most suitable linden for landscape use in similar climate regions to Auburn, Ala.

\section{Literature cited}

Ashby, W.C. 1962. Budbreak and growth of basswood as influenced by daylength, chilling and gibberellic acid. Bot. Gaz. 123:162-170

Couvillon, G.A. and A. Erez. 1985. Influence of prolonged exposure to chilling temperatures on budbreak and heat requirement for bloom of several fruit species. J. Amer. Soc. Hort. Sci. 110:47-50.

Dirr, M.A. 1998. Manual of woody landscape plants: Their identification, ornamental characteristics, culture, propagation and uses. Stipes Publ., Champaign, Ill.

Dokoozlian, N.K. 1999. Chilling temperature and duration interact on budbreak of 'Perlette' grapevine cuttings. Hort-
Science 34:1054-1056.

Kriebel, H.B. and C.W. Wang. 1962. The interaction of provenance and degree of chilling in budbreak of sugar maple. Silv. Gen. 11:125-130.

Mahmood, K., J.G. Carew, P. Hadley, and N.H. Battey. 2000. The effect of chilling and post-chilling temperatures on growth and flowering of sweet cherry (Prunus avium L.). J. Hort. Sci. Biotechnol. 75:598-601.

Murray, M.B., M.G.R. Cannell, and R.I. Smith. 1989. Date of budburst of fifteen tree species in Britain following climatic warming. J. Appl. Ecol. 26:693-700.

Neter, J., M.H. Kutner, C.J. Nachtsheim, and W. Waserman. 1996. Applied linear statistical models. $4^{\text {th }}$ ed. Times Mirror Higher Educ. Group, Inc., Chicago, Ill.

Perry, T.O. and H. Hellmers. 1973. Effects of abscisic acid on growth and dormancy of two races of red maple. Bot. Gaz. 134:283-289.

Powell, A., D. Himelrick, W. Dozier, and D. Williams. 1999. Fruit culture in Alabama-Winter chilling requirements. Ala. Coop. Ext. Sys. Bul. ANR-53-D.

Roberts, J.J. and J.J. Zwiazek. 1999. Periodic chilling exposure during nursery culture: Effects on growth, morphology, and drought resistance of containerized white spruce seedlings. New Forests 18:301314.

Sibley, J.L., D.J. Eakes, C.H. Gilliam, G.J. Keever, and W.A. Dozier, Jr. 1995. Growth and fall color of red maple selections in the southeastern United States. J. Environ. Hort. 13:51-53.

Sibley, J.L., J.M. Ruter, and D.J. Eakes. 1999. Growth periodicity for containergrown red and Freeman maple cultivars in AHS heat-zone 8. J. Environ. Hort. 17:141-146.

Townsend, A.M., J.W. Wright, W.F. Beineke, R.P. Guries, and C.A. Mohn. 1982. Early patterns of flowering, winter injury, and flushing of red maple progenies grown in five locations. Can. J. For. Res. 12:814-821.
Production of High-quality Tomato

\section{Transplants with a Novel Buffered Fertilizer}

\author{
Kathleen M. Brown, ${ }^{1}$ \\ Charles S. Vavrina, ${ }^{2}$ \\ Robert Snyder, ${ }^{1}$ \\ Mike Orzolek, ${ }^{1}$ and \\ Jonathan P. Lynch ${ }^{1}$
}

AdDitional INDEX WORDS. Lycopersicon esculentum, phosphorus, root development, runoff

\begin{abstract}
Summary. 'FTE 30' tomato
(Lycopersicon esculentum) transplants were produced in Florida under standard commercial conditions and supplied with one of six treatments: zero, low ( $20 \%$ of the control rate), or high (control) super-phosphate (SP) fertilizer, or $0.5 \%, 1 \%$, or $2 \%$ bufferedphosphorous fertilizer (Al-P). Growth characteristics were evaluated for four sets of transplants, produced in January, April, May, and August. Two sets of transplants were grown in the field in Florida (started in January and August) and one set was grown in Pennsylvania during the summer (started in May). Phosphorus concentration in leachate was measured weekly from one crop. Plants grown with Al-P showed a $72 \%$ to $88 \%$ reduction in $\mathrm{P}$ released in leachate compared with the high SP control. Transplants produced with $1 \%$ or $2 \%$ Al-P were of equal size and quality compared with transplants produced with conventional (high SP) fertilization, and had greater total root length and specific root length (length per unit root weight). Transplants grown with $0.5 \% \mathrm{Al}-\mathrm{P}$ were sometimes smaller than other fertilized treatments, while no-P plants were very small and grew slowly after transplanting. There were no significant differences in growth, yield, or fruit quality of plants from
\end{abstract}

${ }^{1}$ Department of Horticulture, Pennsylvania State Uni-
versity, University Park, PA 16802 .
${ }^{2}$ Southwest Florida Research and Education Center, 2686 State Road 29 North, Immokalee, FL 34142. 